www.jmscr.igmpublication.org

Impact Factor 3.79

Index Copernicus Value: 5.88

ISSN (e)-2347-176x ISSN (p) 2455-0450

crossref DOI:_http://dx.doi.org/10.18535/jmscr/v4i1.21

Journal Of Medical Science And Clinical Research

\title{
Comparative Study between Serum and Salivary Cortisol Levels to Assess Adrenal Cortisol Insufficiency in Patients with Cirrhosis
}

\author{
Authors \\ Amr A.bdel Moety ${ }^{1}$, Amal R.Mansour ${ }^{2}$, Eman Zaki Azzam $^{3}$, Rehab Ali Elsayed ${ }^{1}$ \\ ${ }^{1}$ Department of Internal Medicine (Hepatology Unit), University of Alexandria, Egypt \\ ${ }^{2}$ Department of Clinical and Chemical Pathology, University of Alexandria, Egypt \\ ${ }^{3}$ Department of Internal Medicine (Endocrinology Unit), University of Alexandria, Egypt \\ Corresponding Author \\ Rehab Ali
}

Department of Internal Medicine (Hepatology Unit), University of Alexandria, Egypt

Phone:+201004643869, Fax: 002034862506

Email:d_r_rehab@yahoo.com

\begin{abstract}
The reduction in the synthetic function of the liver in patients with liver cirrhosis makes measuring of total serum cortisol invalid because of the prevalence of hypoalbuminemia and the decreased level of cortisol binding globulin in these patients. Salivary cortisol concentrations accurately reflect the free cortisol level in non cirrhotic patients because the unbound portion of cortisol in the blood freely diffuse into saliva which represent the fraction which diffuses to the target tissues of the body.

Aims: To study the correlation between salivary, serum total cortisol and calculated free cortisol. The prevalence of cortisol insufficiency using salivary and serum assays. Parameters associated with the discrepancy between both tests in cirrhotic patients.

Methods: Fasting serum cortisol was assessed using ADVIA Centur Autoanalizer together with salivary cortisol using Salimetrics Salivary assay kit cat. \#1-3002 5pk 1-32002-5-USA at 8 AM. Pituitary hypoadrenalism will be excluded in patients with total cortisol level less than $4 \mu \mathrm{g} / \mathrm{dl}$.

Results: Salivary cortisol and calculated free cortisol are significantly correlated to adrenal function in cirrhotic patients more than serum total cortisol.

Conclusion: Salivary cortisol levels are the most accurate to asses adrenal cortical function in cirrhotic patients.
\end{abstract}

\section{Introduction}

Ninety to ninety five of serum cortisol is bounded to plasma proteins divided as $60 \%$ bounded to corticosteroid binding protein (CBG)and $30 \%$ bounded to albumin while the remaining represent the free active part of cortisol.

The usual way to measure cortisol level in serum reflects the bounded form which gives false results in conditions affecting serum proteins as in pregnancy, the use of oral contraceptive pills, liver cirrhosis and kidney diseases. 
Salivary cortisol serves as a reliable, simple and accurate method to measure free cortisol level as free cortisol is transferred from serum to saliva by free diffusion through the acinar cells of salivary glands In cases of liver cirrhosis not only the synthesis of serum proteins is affected, but liver is also the primary site of metabolism of adrenal steroid hormones and the synthesis of cholesterol therefore preexisting liver dysfunction further disturb the hypothalamic

\section{Methodology}

The study included 10 persons completely free from any liver and endocrinal disease to form the control group GI and 50 patients with liver cirrhosis admitted to Alexandria main university hospital to form GII

All patients were subjected to all of the following:

- Complete history taking emphasizing symptoms of liver disease, history of pituitary or adrenal disease, drug history and cause of admission.

- Complete clinical examination stressing on vital signs to assess hemodynamic stability of the patient. Signs of liver cirrhosis were also reported.

- Calculation of body mass index in $\mathrm{kg} / \mathrm{m}^{2}$.

- Laboratory workup which included:

- Complete blood picture

- Liver function profile

- Fasting serum total cortisol at 8 AM using AFIVA Centur Autoanalyzer. Any patients showed serum cortisol level less than $4 \mu \mathrm{g} / \mathrm{dl}$ was subjected to further assessment of pituitary gland function via estimating ACTH level and dynamic test using synactan depot IM (tetracosactide hexaacetate) and cortisol levels were further assessed after 2 and 24 hours of its administration.

Patient preparation and specimen collection:

Chewing gums or brushing teeth should be avoided for 30 minutes before sampling.

Saliva samples will be collected using special saliva sampling devices (salivette Sarstedt .cat\#51.1534-USA).

If there is blood contamination in the pateint's specimen, it was discarded and anew sample was taken after 10 minutes.

- Fasting salivary cortisol was assessed using salimetrics salivary assay kit cat.\#1-30025PK13002-5USA at 8 AM. The salivary cortisol was rechecked for those patients having low fasting serum cortisol after 2 and 24 hours after synactan depot injection.

- Lipid profile including cholesterol, triglycerides and HDL by autoanalyzer dimension -USA.

- CBG using enzyme linked immunosorbant assay (E91226Hu96testsUSA).

- Calculated free cortisol (CFC) was obtained using Coolens formula $\mathrm{CFC}=\sqrt{ }$ $\left(\mathrm{Z}^{2}+0.0122 * \mathrm{STC}\right)-\mathrm{Z}$.

$\mathrm{Z}=0.0167+0.182(\mathrm{CBG}-\mathrm{STC})$.

- The severity of liver disease was classified according to Child -Pugh classification.

- Imaging study which included plain chest $\mathrm{X}$ ray and abdominal ultrasound to evaluate the presence of ascites and or spleenomegaly.

- A written informed consent from each person who shared in this study was included. 


\section{Results}

After data were collected, it was revised, coded and fed to statistical software SPSS version 16. All statistical analysis was done using two tailed tests and alpha error of $0.05 \mathrm{P}$ valueless than or equal to 0.05 was considered to be significant.

Figure 1: lipid profile among control G1 and patients GII

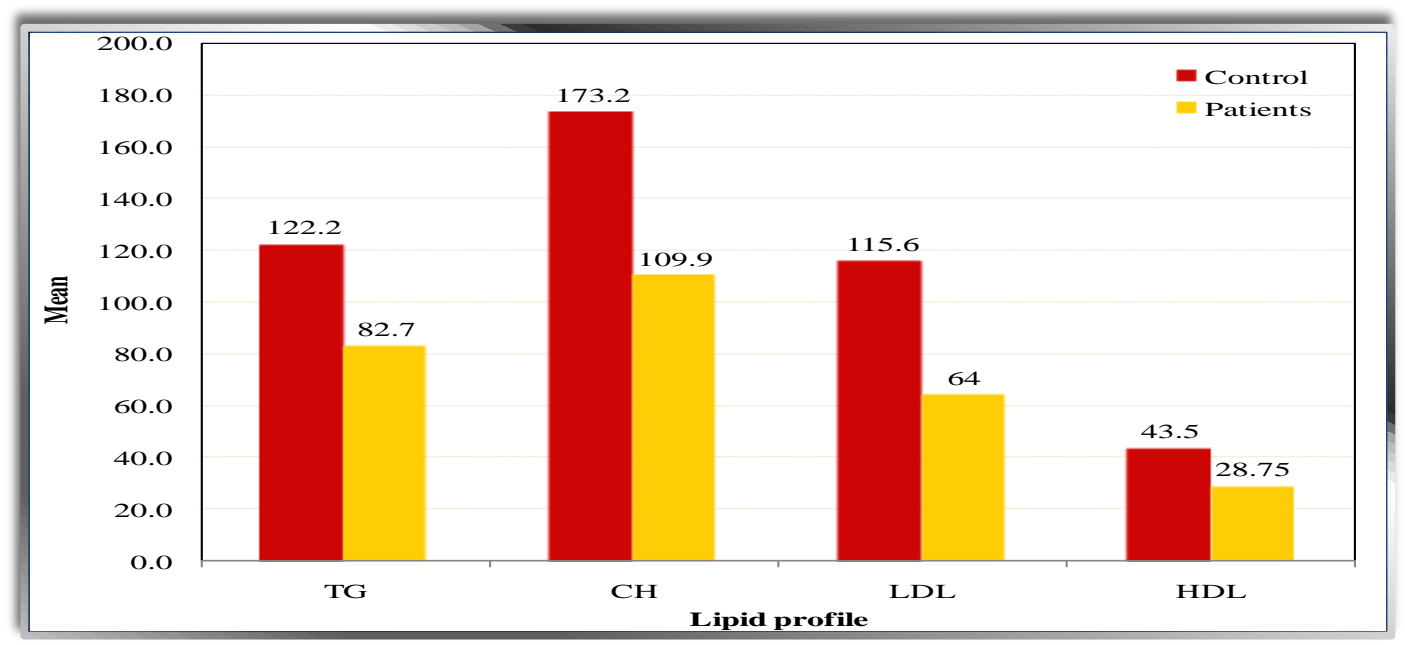

Figure 2: comparison between control G1 and patients GII as regards different laboratory investigations

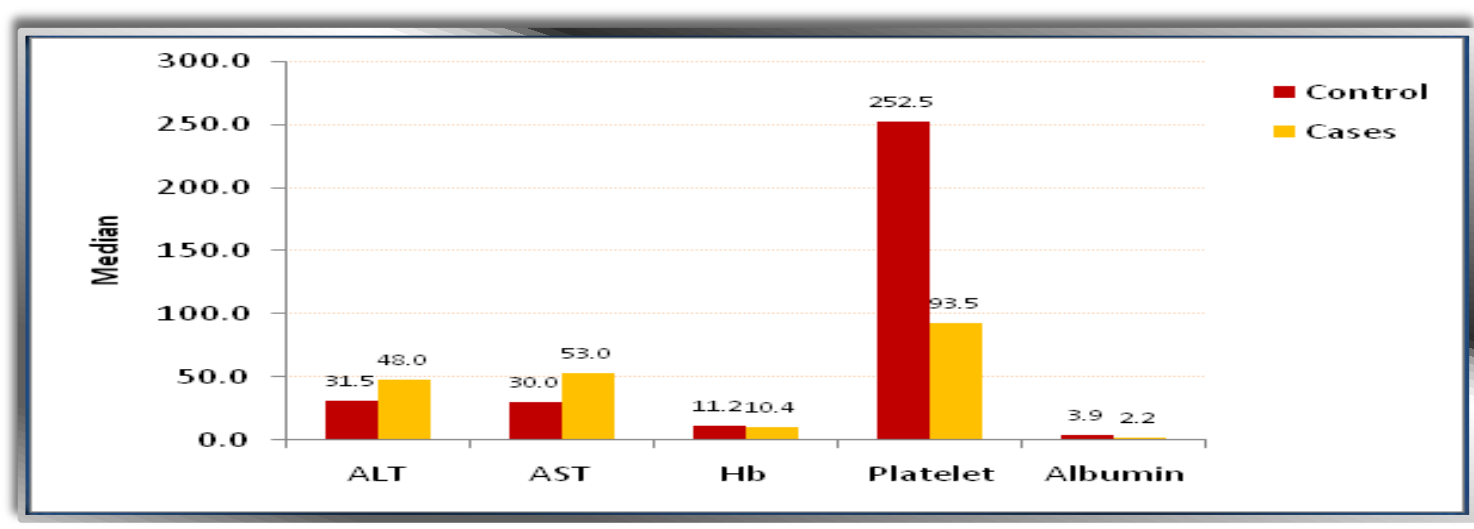

Table 1: Mean and standard deviation of of salivary cortisol, serum total cortisol, corticosteroid binding globulin, and the calculated free cortisol among control (GI) and patients (GII)

\begin{tabular}{|l|l|l|l|l|l|}
\hline \multicolumn{2}{|l|}{ Control (GI) } & \multicolumn{2}{l|}{ Patients (GII) } \\
\cline { 2 - 6 } & Mean & SD & Mean & SD \\
\hline Salivary Cortisol & 6.84 & 1.48 & 4.83 & 0.97 & $0.000 *$ \\
\hline Total Serum Cortisol & 14.30 & 4.19 & 14.22 & 4.94 & 0.962 \\
\hline CBG & 64.60 & 27.50 & 72.86 & 52.80 & 0.633 \\
\hline CFC & 0.150 & 0.291 & 0.121 & 0.225 & 0.728 \\
\hline
\end{tabular}


Table 2: Correlations between salivary cortisol, total serum cortisol and calculated free cortisol among control (GI) and patients (GII)

\begin{tabular}{|c|c|c|c|c|}
\hline Group & & & & $\mathrm{CFC}$ \\
\hline \multirow{7}{*}{ Control (GI) } & \multirow{7}{*}{ Spearman's rho } & \multirow{3}{*}{ Salivary cortisol } & Correlation coefficient & $0.867(* *)$ \\
\hline & & & Sig. (2-tailed) & 0.001 \\
\hline & & & $\mathbf{N}$ & $\mathbf{1 0 . 0}$ \\
\hline & & \multirow{4}{*}{ Serum total cortisol } & Correlation coefficient & 0.408 \\
\hline & & & & \\
\hline & & & Sig. (2-tailed) & 0.242 \\
\hline & & & $\mathbf{N}$ & 10.0 \\
\hline \multirow{6}{*}{$\begin{array}{l}\text { Patients } \\
\text { (GII) }\end{array}$} & \multirow{6}{*}{ Spearman's rho } & \multirow{3}{*}{ Salivary cortisol } & Correlation coefficient & $0.653(* *)$ \\
\hline & & & Sig. (2-tailed) & 0.000 \\
\hline & & & $\mathbf{N}$ & 50.0 \\
\hline & & \multirow{3}{*}{ Serum total cortisol } & Correlation coefficient & $0.416(* *)$ \\
\hline & & & Sig. (2-tailed) & 0.003 \\
\hline & & & $\mathbf{N}$ & $\mathbf{5 0 . 0}$ \\
\hline
\end{tabular}

Table 3: Correlations between salivary cortisol, with total serum cortisol among control (GI) and patients (GII)

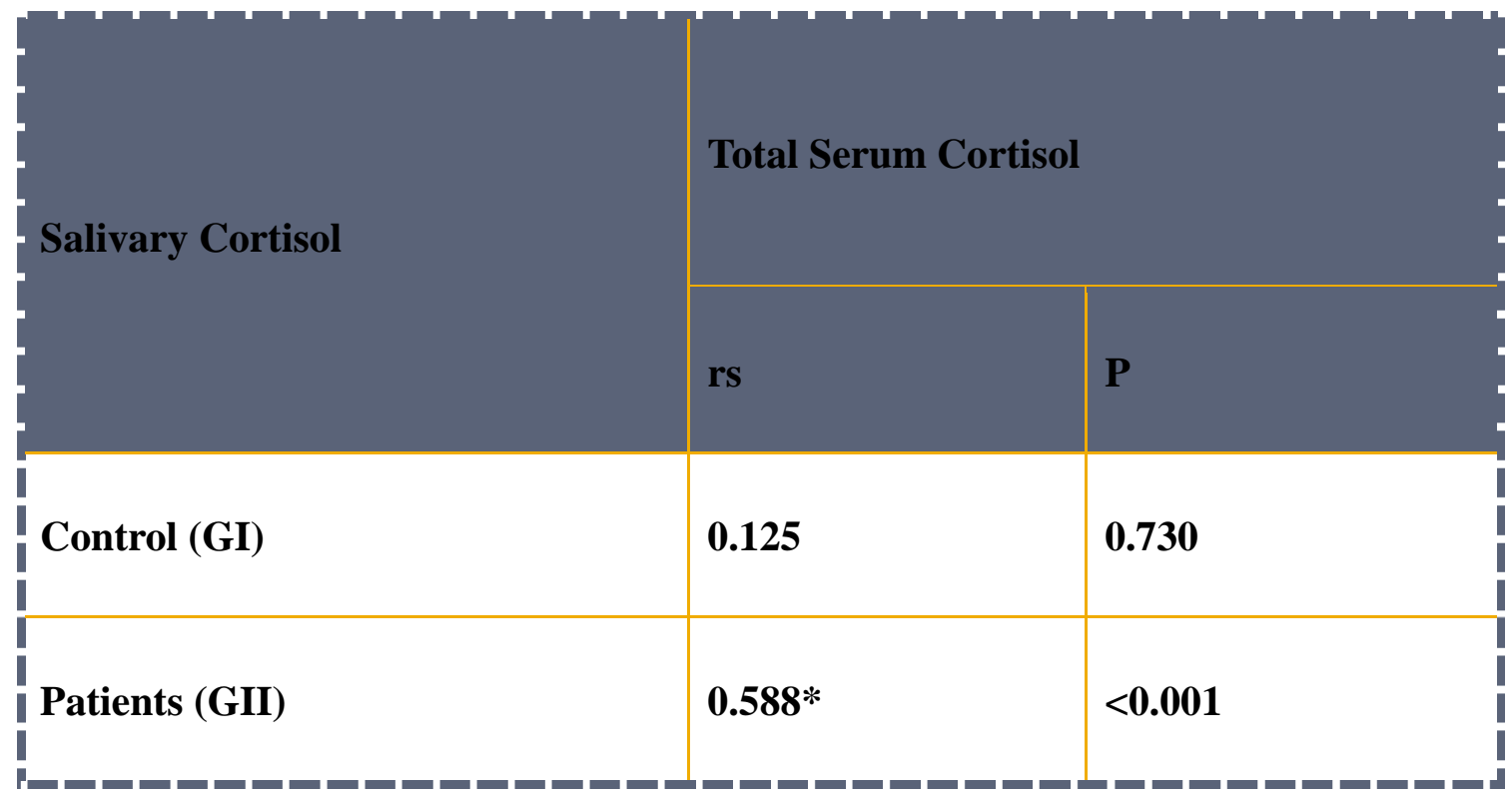




\section{JMSCR Vol||04||Issue||01||Page 8911-8918||January}

Table 4 : Comparison of corticosteroid binding globulin among control (GI) and patients (GII)

\begin{tabular}{|c|c|c|c|c|c|c|c|c|}
\hline & & \multicolumn{5}{|c|}{ CBG } & \multirow{2}{*}{$\mathbf{Z}$} & \multirow{2}{*}{$\mathbf{P}$} \\
\hline & & Min & Max & Median & Mean & SD & & \\
\hline \multicolumn{7}{|c|}{ Group } & \multirow{3}{*}{0.021} & \multirow{3}{*}{0.984} \\
\hline & - $\mathbf{G ~ I}$ & 15.0 & 99.0 & 60.5 & 64.6 & 27.5 & & \\
\hline & - G II & 9.0 & 227.0 & 61.0 & 69.71 & 42.0 & & \\
\hline \multicolumn{7}{|c|}{ Child classification } & \multirow{4}{*}{$\mathrm{X} 2=\mathbf{0 . 8 3 8}$} & \multirow{4}{*}{0.658} \\
\hline & - $\mathbf{A}$ & 25.0 & 132.0 & 84.0 & 77.3 & 44.1 & & \\
\hline & - $\mathbf{B}$ & 9.0 & 227.0 & 56.0 & 65.92 & 42.98 & & \\
\hline & - $\mathbf{C}$ & 25.0 & 158.0 & 62.5 & 74.0 & 41.4 & & \\
\hline \multicolumn{7}{|c|}{$\mathrm{HCC}$} & \multirow{3}{*}{3.343} & \multirow{3}{*}{0.068} \\
\hline & - No & 9.0 & 227.0 & 57.0 & 64.86 & 42.71 & & \\
\hline & - Yes & 42.0 & 158.0 & 83.0 & 86.0 & 36.7 & & \\
\hline
\end{tabular}

Table 5 : Correlation between CBG with albumin in control (GI) and patients (GII)

\begin{tabular}{|l|l|l|}
\hline \multirow{2}{*}{ Albumin } & CBG & \\
\cline { 2 - 3 } & rs & P \\
\hline Control (GI) & $\mathbf{0 . 0 1 2}$ & $\mathbf{0 . 9 7 3}$ \\
\hline Patients (GII) & $\mathbf{- 0 . 0 8 1}$ & $\mathbf{0 . 5 7 7}$ \\
\hline
\end{tabular}

Table 6: Correlation between corticosteroid binding globulin and salivary cortisol, serum total cortisol and calculated free cortisol among control (GI) and patients (GII)

\begin{tabular}{|c|c|c|c|}
\hline \multirow{2}{*}{ Group } & & \multicolumn{2}{|l|}{ CBG } \\
\hline & & $\mathbf{r}$ & $\mathbf{P}$ \\
\hline \multirow[t]{3}{*}{ Control (GI) } & Salivary Cortisol & -0.42 & 0.231 \\
\hline & Total Serum Cortisol & -0.27 & 0.458 \\
\hline & CFC & -0.65 & $0.043 *$ \\
\hline \multirow[t]{3}{*}{ Patients (GII) } & Salivary Cortisol & 0.01 & 0.968 \\
\hline & Total Serum Cortisol & -0.07 & 0.615 \\
\hline & CFC & -0.16 & 0.262 \\
\hline
\end{tabular}


Table 7: Correlation between albumin and salivary cortisol, serum total cortisol and calculated free cortisol in (GII)

\begin{tabular}{|c|c|c|c|c|c|}
\hline Hypoalbuminemia & & & $\begin{array}{l}\text { Salivary } \\
\text { Cortisol }\end{array}$ & $\begin{array}{l}\text { Serum total } \\
\text { Cortisol }\end{array}$ & CFC \\
\hline \multirow{6}{*}{ Yes } & \multirow{2}{*}{ Salivary Cortisol } & $\mathbf{r}$ & & 0.573 & 0.640 \\
\hline & & $\mathbf{P}$ & & $0.000 *$ & $0.000 *$ \\
\hline & \multirow{2}{*}{ Serum total Cortisol } & $\mathbf{r}$ & 0.573 & & 0.390 \\
\hline & & $\mathbf{P}$ & $0.000 *$ & & $0.007 *$ \\
\hline & \multirow{2}{*}{ CFC } & $\mathbf{r}$ & 0.640 & 0.390 & \\
\hline & & $\mathbf{P}$ & $0.000 *$ & $0.007 *$ & \\
\hline \multirow{6}{*}{ No } & \multirow{2}{*}{ Salivary Cortisol } & $\mathbf{r}$ & & 0.227 & 0.621 \\
\hline & & $\mathbf{P}$ & & 0.456 & 0.024* \\
\hline & \multirow{2}{*}{ Serum total Cortisol } & $\mathbf{r}$ & 0.227 & & 0.572 \\
\hline & & $\mathbf{P}$ & 0.456 & & $0.041 *$ \\
\hline & \multirow{2}{*}{ CFC } & $\mathbf{r}$ & 0.621 & 0.572 & \\
\hline & & $\mathbf{P}$ & $0.024 *$ & $0.041 *$ & \\
\hline
\end{tabular}

\section{Discussion}

Adrenal failure is a dynamic process and repeated adrenal function testing is indicated in patients who remain hemodynamically unstable or fail to improve with aggressive supportive treatment.

The mechanism of adrenal insufficiency in liver cirrhosis is not completely understood, although decreased levels of HDL, cholesterol together with high levels of proinflammatory cytokines, endotoxins, structural damage of adrenal glands due to hemorrhage or infarction, bacterial translocation of enteric organisms and glucocorticoid resistance may be suggested.

In this study salivary cortisol was significantly correlated more than calculated free cortisol and serum total cortisol signifying that the salivary cortisol is more accurate and related more to the free active part of cortisol thus better reflection of adrenal function in patients with liver cirrhosis. Calculated free cortisol was indirectly estimated by Coolen's formula, which is of limited usefulness and should be used with caution. Many studies concluded that the paired values of free cortisol levels obtained from direct methods and those obtained from calculation had a magnitude of bias that would expected to produce clinically relevant discrepancies and this limits the usefulness of Coolen's formula.

Salivary cortisol in GII was significantly lower than G1 signifying low cortisol level, it was reduced in $60 \%$ of patients and subsequently those patients had relative adrenal insufficiency as it did not reach the level of frank adrenal insufficiency.

In this study calculated free cortisol had negative significant correlation with CBG but in GII there was no correlation. While in both groups there was no correlation between salivary cortisol and CBG emphasizing that salivary cortisol was independent from $\mathrm{CBG}$ and more accurate to be used in patients with liver cirrhosis. CBG was statistically insignificant between both groups and Child -Pugh classification or presence or absence of HCC. CBG was also not correlated with albumin level in both groups.

In patients with normal albumin level, the calculated free cortisol was more correlated with salivary cortisol than with serum total cortisol. While salivary cortisol was insignificantly correlated with total cortisol. In patients with hypoalbuminemia, calculated free cortisol was more correlated with salivary cortisol than serum total cortisol. 
The mean triglyceride (TG) level in (GII) patients was significantly lower than control group (GI). The mean cholesterol level in (GII) patients was significantly lower than control group (GI). Also, the mean low density lipoprotein (LDL) in (GII) patients was significantly lower than control group (GI), and the mean high density lipoprotein (HDL) in patients (GII) patients was significantly lower than control group.

\section{Conclusion}

Measurement of salivary cortisol in patients with low corticosteroid binding globulin (CBG) level or hypoalbuminemia is simple, easy to measure in most laboratories, and provides a direct and reliable and practical assessment of the serum free cortisol concentrations during critical illnesses.

Relative adrenal insufficiency in liver cirrhosis is more prevalent than it thought to be as the known ways of its diagnosis are not reliable.

Coolens' formula used in calculating free cortisol is inaccurate as it depends on CBG which is almost affected by the liver disease.

\section{References}

1. Daughday WH, Mariz UK. Corticosteroid-binding globulin: its prosperities and quantitation. Metabolism 1961; 10:936-50.

2. Brien T. G.Human corticosteroid binding globulin.Clinical endocrinology 1981; 14(2):193-212.

3. Meulenberg PPM, Ross HA, Swinkels LMJW, et al. The effect of oral contraceptives on plasma-free and salivary crtisol and cortisone.Clin Chem Acta 1987; 165:379-85.

4. Arafah BM, Nishiyama FJ, Tlaygeh H, et al. Measurement of salivary cortisol concentration in the assessment of adrenal function in critically ill subjects: a surrogate marker of the circulating free cortisol. J Clin Endocrinol Metab 2007; 92(8):2965.

5. McCann VJ, Fulton TT. Cortisol Metabolism in Chronic Liver Disease. The Journal of Clinical Endocrinology \& Metabolism 1975; 40:1038-1044.

6. Dickerman Z, Grant OR, Faiman C, et al. Intraadrenal steroid concentration in man:Zonal differences and developmental changes. J Clin Endocrin Metab 1984; 59:1031.

7. Kyrou I, Tsicgos C. Hypothalamic - pituitary_adrenal axis in: Adrenal glands diagnostic aspects and surgical therapy, Lions D, Van Heerden JA. Springer, New York 2005; 19-32.

8. Dickmeis T. Glucocorticoids and the circadian clock. J Endocrinol 2009; 200(1):3.

9. Giordano R, Pellegrino M, Picu A, et al. Neuroregulation of the hypothalamus-pituitary-adrenal (HPA) axis in humans: effects of GABA-, mineralocorticoid-, and GH-Secretagogue-receptor modulation. Scientific World Journal 2006; 6:1.

10. Souvatzoglous A. The sympathoadrenal system integrative regulation of the cortical and medullary adrenal function in: adrenal glands diagnostic aspects and surgical therapy Lions D, Van Hereden JA, Springer newyork 2005; 33:40.

11. Parisio G, Sperotto MM, Ferrarini A. Flip flop of steroids in phospholipid bilayer: effects of chemical structure on transbilayer diffusion .J Ann Chem soc 2012; 134(29)12198-208.

12. Arafah BM,Nishiyama FJ,Tlaygeh H,Hejal R.Measurement of salivary cortisol concentration in the assessment of adrenal function in critically ill subjects : a surrogate marker of the circulating free cortisol .J Clin Endocrinal Metab 2007;92:2965-71.

13. Raff H,Brock S,Findling JW.cosyntropin -stimulated salivary cotisol in hospitalized patients with hypoproteinemia .Endocrine 2008;34:68-74.

14. Arregger AL,Caroso EM,Tumilasci O,Contreras LN. Diagnostic value of salivary cortisol in end stage renal disease .Steroids 2008;73:77-82. 
15. Cardoso E,Persi G,Gonzalez N,Tmilasci O,Arregger A,Burgos M,Rodriguez V,Molina A, Contreras LN.Assessment of adrenal function by measurement of salivary steroids in response to corticotrophin in patients infected with human immunodeficiency virus .Steroids 2007;72:328-334.

16. Galbois A, Rudler M, Massard J, Fulla Y, Bennani A, Bonnefont-Rousselot D, Thibault V, Reignier S, Bourrier A, Poynard T, Thabut D. Assessment of adrenal function in cirrhotic patients: salivary cortisol should be preferred. J Hepatol.2010;52(6):839-45.

17. Umeda T,Hiramatsu R ,Iwaoka T,Shimda T, Miura F,Sato T.Use of saliva for monitoring unbound free cortisol levels in serum .Clin Chim Acta 1981;110:245-253.

18. Gozansky WS,Lynn JS,Laudenslager ML,Kohrt WM.Salivary cortisol determined by enzyme immunoassay is preferable to serum total cortisol for assessment of dynamic hypothalamic -pituitary -adrenal axis activity. Clin Endocrine (Oxf) 2005;63:336-341.

19. Estrada-Y-Martin RM, Orlander PR. Salivary cortisol can replace free serum cortisol measurements in patients with septic shock 2011;140(5):1216-22.

20. Cohen, J.a,Venkatesh, B.bc,Tan, T.cd. Comparison of the diagnostic accuracy of measured and calculated free cortisol in acutely ill patients using the Coolens equation. Crit. Care and Resu;2013, (15)39-41.

21. Pretorius CJ, Galligan JP, McWhinney BC, Briscoe SE, Ungerer JP. Free cortisol method comparison: Ultrafiltation, equilibrium dialysis, tracer dilution, tandem mass spectrometry and calculated free cortisol. Clinica Chimica Acta.2011; 412(11-12) 1043-47.

22. Barlow NL, Holme J, Stockley RA, Clark PM. An evaluation of measured and calculated serum free cortisol in a group of patients with known adrenal suppression. Ann Clin Biochem. 2010;47(3):2004.

23. Venkataraman S et al.The hypothalamic- pituitary-adrenal axis in critical illness. Rev Endocr Metab Disord 2007;8: 365-373.

24. Hamrahian AH, Oseni TS, Arafah BM. Measurements of serum free cortisol in critically ill patients. N Engl J Med 2004;350:1629-1638.

25. Molenaar N, Johan Groeneveld AB, Dijstelbloem HM, de Jong MF, Girbes AR,Heijboer AC, Beishuizen A. Assessing adrenal insufficiency of corticosteroid secretion using free versus total cortisol levels in critical illness. Intensive Care Med 2011;37(12):1986-93.

26. Trifan A, Chiriac S, Stanciu C. Update on adrenal insufficiency in patients with liver cirrhosis. World J Gastroenterol. 2013 Jan 28;19(4):445-56.

27. Yamamoto M, Ariyoshi Y, Matsui N, The serum concentrations of unbound, transcortin bound and albumin bound cortisol in patients with dysproteinemia .

28. Ghadir MR, Riahin AA, Havaspour A, Nooranipour M, Habibinejad AA. The relationship between lipid profile and severity of liver damage in cirrhotic patients. Hepat Mon 2010; 10(4):285-8.

29. Mandal SK, Koelina S, Sumanta C, Jacky G, Koushik C, Pankaj S, et al. A Study on lipid profiles in chronic liver Diseases. Nat J Med Res 2013; 3:70-2. 